\title{
Aktualisasi Pendidikan Life Skill Untuk Meningkatkan Nilai-nilai Spiritual Santri di Pondok Pesantren Al-0odiri Jember
}

\author{
Syaiful Rizal, Nardiyanto \\ Dosen Institut Agama Islam (IAI) Al-Qodiri Jember \\ Syaifulrizal212@gmail.com,Nardiakbarfarabi@gmail.com
}

\begin{abstract}
This study discusses how the actualization of Life Skill Education to increase the Spiritual Values of the Santri in Al-Qodiri Islamic Boarding School. Researchers use qualitative research methods. The results showed that Life Skill Education really provides and produces positive values for pesantren because students are able to actualize their ability to achieve competence both as individuals and as part of the social community. High intellectual abilities are able to solve life problems faced in order to live an independent and dignified life and be proactive in solving existing problems. The management places the students in the area according to the ability of the students who are assisted by the regional management in exploring the potential of the students through activities in the region. Santri in the region emphasized that they can speak Arabic and read and write the book. Then the students followed the Ta'lim, Tahlilan and Dzikir Manaqib Syaich Abdul Qodir Jaelani. The spiritual values that are emphasized for students are Social Values, Ethics, Morals and Cooperation and Togetherness.
\end{abstract}


Keywords: Life Skills, Spiritual Values and Santri

\begin{abstract}
Abstrak: Penelitian ini membahas tentang bagaimana aktualisasi Pendidikan Life Skill untuk meningkatkan Nilai-nilai Spiritual Santri di Pondok Pesantren Al-Qodiri. Peneliti menggunakan metode penelitian Kualitatif. Hasil Penelitian menunjukkan Pendidikan Life Skill sangat memberikan dan menghasilkan nilai-nilai positif terhadap pesantren dikarenakan santri mampu mengaktualisasikan kemampuan dalam mencapai kompetensi baik sebagai individu ataupun bagian dari masyarakat sosial. Kemampuan intelektual yang tinggi mampu memecahkan permasalah hidup yang dihadapi untuk menjalani kehidupan yang mandiri dan bermartabat serta proakt if dalam ikut menyelesaikan permasalahan yang ada. Pengurus menempatkan santri di wilayah sesuai dengan kemampuan santri yang dibantu pengurus wilayah dalam menggali potensi santri melalui kegiatan di wilayah. Santri di wilayah ditekankan bisa berbahasa Arab dan Baca Tulis Kitab. Kemudian santri mengikuti Majelis Ta'lim, Tahlilan dan Dzikir Manaqib Syaich Abdul Qodir Jaelani. Nilai-nilai spiritual yang ditekankan bagi santri yakni Nilai Sosial, Etika, Moral dan Kerja Sama dan Kebersamaan.
\end{abstract}

Kata Kunci: Life Skill, Nilai-nilai spiritual dan Santri

\title{
Pendahuluan
}

Pendidikan adalah persoalan hidup yang paling menarik di antara persoalan persoalan pokok kehidupan lain seperti ekonomi, politik, dan keamanan. Hal ini karena pendidikan sangat erat kaitannya dengan kelangsungan generasi yang akan datang. Siapa yang memegang pendidikan dialah yang akan memegang masa depan. Atas dasar itu, masyarakat berlomba lomba ikut menentukan arah penyelenggaraan pendidikan dan menyelenggarakan pendidikan secara langsung.

Tujuan pendidikan pada hakekatnya harus berupaya menciptakan suasana belajar dan proses pembelajaran yang dapat memberikan bekal bagi peserta didik dengan berbagai kecakapan hidup (life skill). Pendidikan 
tidak hanya mengejar pengetahuan semata tetapi harus ada proses pengembangan keterampilan, sikap dan nilai-nilai tertentu yang dapat direfleksikan dalam kehidupan peserta didik dimasa yang akan datang. ${ }^{1}$

Konsep kecakapan hidup (life skill) telah lama menjadi perhatian para ahli dalam pengembangan kurikulum. Misalnya mengemukakan bahwa kecakapan hidup merupakan salah satu fokus analisis dalam pengembangan kurikulum pendidikan yang menekankan kepada kecakapan hidup. Pengembangan kecakapan hidup yang mengedepankan kepada aspek-aspek sebagai berikut: Kemampuan yang relevan untuk dikuasai peserta didik, materi pembelajaran sesuai dengan tingkat perkembangan peserta didik, kegiatan pembelajaran dan kegiatan peserta didik untuk mencapai kompetensi, fasilitas, alat dan sumber belajar yang memadai dan kemampuan-kemampuan yang dapat diterapkan dalam kehidupan peserta didik. ${ }^{2}$

Dalam hal ini dapat dikemas bahwa pendidikan kecakapan hidup (life skill) Sebagaimana di sebutkan pada sistem Pendidikan Nasional, pasal 26 ayat 3 UU No. 20 tahun 2003, bahwa pendidikan kecakapan hidup (life skill) ialah pendidikan yang memberikan kecakapan personal, sosial, intelektual dan kecakapan vokasional untuk bekerja atau usaha mandiri. Pendidikan kecakapan hidup merupakan proses pendidikan yang menyiapkan seseorang untuk mampu mengaktualisasikan kemampuan dalam mencapai kompetensi baik sebagai individu ataupun dari bagian masyarakat sosial, kemampuan intelektual yang tinggi, mampu memecahkan permasalahan hidup yang dihadapi, dan siap menjalani hidup yang mandiri dan bermartabat, serta proaktif ikut menyelesaikan permasalahan yang ada. ${ }^{3}$

Di zaman yang segalanya telah berubah yang ditandai dengan era globalisasi serta perkembangan ilmu dan teknologi, tentu pondok pesantren di tuntut untuk mengikuti perkembangan tersebut. Pondok pesantren tidak tetap kukuh dengan segala ketradisionalannya untuk mengembangkan pola pikir, kepribadian dan masa depan para santrinya.

1 Jurnal EMPOWERMENT, Volume 3, Nomor 1 Febuari 2015, ISSN No. 2252-4738.

2 Ibid

3 M. Holil, Pesantren Berbasis Life Skill (Situbondo: IAI Ibrahimy, 2015), 235. 
Ini dibutuh kekuatan ekstra dari seluruh pihak luar dalam guna lebih meningkatkan kualitas santri, baik di bidang keagamaan, intelaktual, bahkan terhadap Life Skill yang mumpuni bagi para santri. Ini mutlak harus dikembangkan oleh sebuah pesantren agar eksitensinya tetap kokoh dan tak tergeruh oleh zaman yang serba berorientasi pada hal yang produktif. Santri yang akan lulus dari sebuah pondok pesantren tidak akan mampu produktif bila tidak mendapatkan pendidikan yang mumpuni dari pesantren itu sendiri. Sebab pendidikan merupakan salah satu penunjang yang sangat mendasar bagi perubahan dan kemajuan sebuah masyarakat.

Betapa pentingnya pendidikan bagi kehidupan manusia, Rasulullah mengatakan bahwa beliau diutus sebagai pendidik: "RasulullahSAW bersabda:

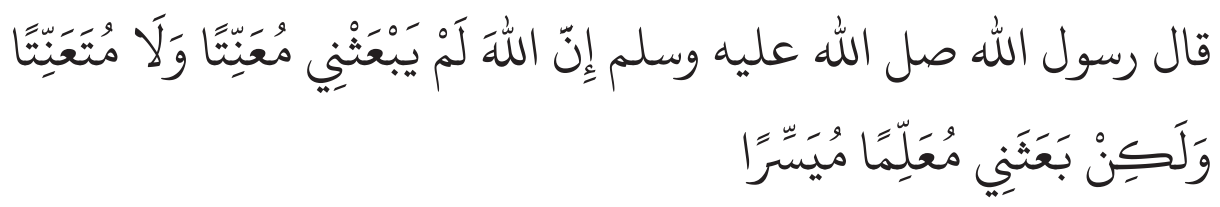

Artinya:

"Allah tidak mengutusku sebagai orang yang menyusahkan tapi Allah mengutusku sebagai pendidik yang memudahkan" (HR. Muslim ). ${ }^{4}$

Manusia diciptakan Tuhan sebagai mahluk terbaik dengan berbagai potensi yang tidak diberikan kepada makhluk lainnya. Namun apabila manusia tidak bisa mengembangkan potensinya bisa saja ia menjadi lebih rendah dari makhluk lain, bahkan seperti hewan. ${ }^{5}$ Manusia terdiri dari dua unsur, unsur jasmani dan rohani. Unsur jasmani membutuhkan pemenuhan yang bersifat materi, seperti makan, minum, olahraga, dan lain-lain. Adapun unsur rohani adalah unsur yang membutuhkan pemenuhan non materi. Manusia di sebut makhluk rohani karena ia memiliki roh. Roh adalah unsur gen ketuhanan yang ditiupkan dalam

\footnotetext{
${ }^{4}$ HR. Muslim, No. Hadits 2703.

5 S. Khasinah, Hakikat Manusia Menurut Pandangan Islam dan Barat, Jurnal Ilmiah Didaktika, XIII (2) 2013, pp. 296-317.
} 
diri manusia, menjadi diri dan merupakan hakikat manusia yang bersifat rohaniah.

Islam melihat bahwa manusia memiliki beberapa dimensi, yaitu manusia sebagai hamba allah (Abd Allah), manusia sebagai al-Nas, manusia sebagai Khalifah Allah, bani Adam, manusia sebagai al-insan, manusia sebagai makhluk biologis (al-basyar). ${ }^{6}$ Manusia adalah makhluk yang potensial yang memiliki kelebihan yang tidak di miliki makhluk lain, manusia secara fisik dan mental mampu tumbuh dan berkembang, mengalami perubahan dan kematangan. Potensi yang diberikan kepada manusia itu sejalan dengan sifat-sifat Tuhan, dan batas kadar dan kemampuannya sebagai manusia. ${ }^{7}$ Adapun jalaluddin berpendapat bahwa potensi utama manusia adalah fitrah dari Allah kepada manusia, yaitu: potensi naluriah (emosional) atau hidayah al-Ghariyyat, potensi inderawi (fisikal) atau hidayat al-Hasiyat, potensi akal (intelektual) atau hidayat al-Aqliyat, potensi agama (spiritual) atau hidayat al-Diniyat.

Potensi manusia yang sampaikan oleh Langgulung adalah potensi akal (intelektual) atau Hidayat Al-Aqliyat dan potensi spiritual (agama). Fitrah atau potensi spiritual (agama) ini akan mendorong manusia untuk mengakui dan mengabdi kepada sesuatu yang di anggapnya memiliki kelebihan dan kekuatan yang lebih besar dari manusia itu sendiri. Nantinya, pengakuan dan pengabdian ini akan melahirkan berbagai macam bentuk ritual atau upacara-upacara sakral yang merupakan wujud penyembahan atau ibadah manusia kepada Tuhannya. Dalam pandangan Islam kecenderungan kepada agama ini merupakan dorongan yang berasal dari dalam diri manusia sendiri yang merupakan anugerah dari Allah. Dalam Al-Qur’an di jelaskan:

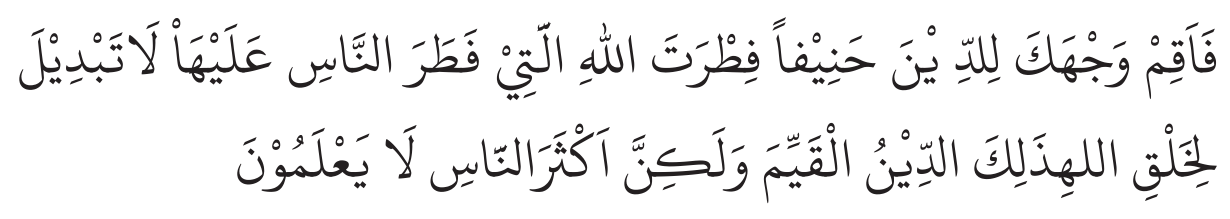

${ }^{6}$ Desmita, Psikologi Perkembangan (Bandung: Rosda Karya, 2007)

7 H. Langgung, Azas-Azas Pendidikan Islam (Jakarta: Pustaka Al-Husna, 2008) 
Terjemahnya:

"Maka hadapkanlah wajahmu dengan lurus kepada agama Allah; (tetaplah atas) fitrah Allah yang telah menciptakan manusia menurut fitrah itu. Tidak ada perubahan pada fitrah Allah. (Itulah) agama yang lurus; tetapi kebanyakan manusia tidak mengetahui."(QS. Ar-Rum:30) ${ }^{8}$

Dari ayat di atas bisa dikatakan bahwa yang dimaksud dengan fitrah Allah adalah ciptaan Allah. Artinya, Allah menciptakan manusia dengan potensi beragama yaitu agama tauhid. Spiritualitas merupakan kebutuhan bawaan manusia untuk berhubungan dengan Dzat Yang Maha Besar jauh di luar sisi kemampuan sebagai manusia. istilah "Yang Lebih Besar dari manusia" adalah yang diluar diri manusia dan menarik perasaan akan diri orang tersebut.

Dari hasil pendahuluan di atas bahwa seorang santri harus mempunyai motivasi, minat dan dapat mengaplikasikan pengetahuan serta keterampilan yang di dapat secara mandiri untuk melaksanakan tugas dan kewajibannya dimasa depan. Berdasarkan dari hal tersebut, maka merupakan suatu alasan yang sangat mendasar apabila penulis membahas tentang pendidikan kecakapan hidup dan nilai-nilai spiritual dalam skripsi yang berjudul: "Aktualisasi Pendidikan Life Skill Untuk Meningkatkan Nilai-Nilai Spiritual Santri Di Pondok Pesantren Al-Qodiri Jember”.

\section{Metode Penelitian}

Penelitian ini dilakukan dengan cara mengambil data dari tempat dimana peneliti melakukan penilaian dengan lebih memfokuskan pada daerah tertentu, maka peneliti menggunakan jenis penelitian Field Research (penelitian lapangan). Penelitipun menggunakan satu lokasi penelitian, yaitu : Pondok Pesantren Al-Qodiri 1 Jember yang beralamatkan Jl. Manggar 139-A RT.002 RW.014 Lingk. Gebang Poreng Kecamatan Patrang Kabupaten Jember Provinsi Jawa Timur.

${ }^{8}$ Kemenag RI, Al-Quran dan Terjemahnya (Jakarta Selatan: PT. Hati Emas, 2014), 404 . 
Sumber data penelitian yang digunakan yaitu Purposive Sampling (sampling pertimbangan) dengan informan yang dipilih adalah ketua pengurus pondok, seksi pendidikan, pengurus daerah, santri, wali santri serta masyarakat. Penelitian dilakukan selama proses kegiatan dipondok 24 Jam yang di mulai pada Tanggal 02 Januari 2020 - 20 Februari 2020.

Dalam menganalisis data, peneliti menggunakan model Miles \& Hubermen, yaitu analisis data yang dilakukan secara interaktif dan berlangsung secara terus-menerus sampai tuntas sehingga datanya mencapai titik jenuh. Adapun runtutan analisisnya adalah sebagai berikut : reduksi data, display data, kongklusi/verifikasi (drawing).

Teknik analisis data yang digunakan dalam penelitian ini adalah menggunakan tekhnik analisis data kualitatif deskriptif (berupa katakata bukan angka). Data-data tersebut mungkin telah dikumpulkan dalam berbagai cara seperti observasi, wawancara, atau intisari rekaman yang kemudian diproses melalui perencanaan, pengetikan atau pengaturan kembali dengan menggunakan tiga langkah, yaitu;

1. Pengumpulan Data

Pengumpulan data merupakan tahap pengumpulan data hasil penelitian di lapangan dalam bentuk deskriptif sesuai dengan catatan kecil (field notes), kemudian catatan deskriptif ini dibuat catatan refleksi yaitu catatan yang berisi komentar, pendapat atau penafsiran peneliti terhadap fenomena yang ditemukan di lapangan.

2. Reduksi data

Reduksi data merupakan wujud analisis yang menajamkan, mengklasifikasikan, mengarahkan, membuang data yang tidak berkaitan dengan aktualisasi pendidikan life skill untuk meningkatkan nilai-nilai spiritual santri di Pondok Pesantren Al-Qodiri Jember, kemudian dibuatkan ringkasan, pengkodean, penelusuran tematema, membuat catatan kecil yang dirasa penting, proses tersebut dilakukan sejak pengumpulan data belum berlangsung, diterapkan pada waktu pengumpulan data dan bersamaan dengan penyajian dan verifikasi data. 
3. Penyajian data

Setelah data dikumpulkan dan dispesifikasikan dilakukan penyajian data dalam bentuk laporan. Namun apabila data yang disajikan perlu direduksi kembali, maka reduksi dapat dilakukan kembali guna mendapatkan informasi yang lebih sesuai dengan aktualisasi pendidikan life skill untuk meningkatkan nilai-nilai spiritual santri di Pondok Pesantren Al-Qodiri Jember, selanjutnya data disederhanakan dan disusun secara sistematik.

4. Penarikan kesimpulan (Verifikasi data)

Penarikan kesimpulan atau verifikasi data dalam penelitian merupakan upaya mencari makna dari komponen-komponen data yang disajikan dengan mencermati pola-pola, keteraturan, penjelasan, konfigurasi dan hubungan sebab akibat.

Lebih jauh lagi, untuk memeriksa keabsahan data maka peneliti memakai validitas data Trianggulasi. Dalam penelitian ini, pemeriksaan datanya menggunakan Trianggulasi Sumber, yang berarti membandingkan dan mengecek balik derajat kepercayaan suatu informasi yang diperoleh melalui waktu dan alat yang berbeda dalam metode kualitatif.

\section{Kerangka Teori}

\section{A. Pendidikan Life Skill}

Secara harfiah, kata life (hidup) skill (cakap) jadi life skill adalah kecakapan hidup. ${ }^{9}$ Adapun kata "cakap" memiliki beberapa arti. Pertama dapat diartikan sebagai pandai atau mahir, kedua sebagai sanggup, dapat atau mampu melakukan sesuatu, dan ketiga sebagai mempunyai kemampuan dan kepandaian untuk mengerjakan sesuatu. ${ }^{10}$ Jadi kata kecakapan berarti suatu kepandaian, kemahiran, kesanggupan atau kemampuan yang dimiliki oleh seseorang untuk menyelesaikan sesuatu. Oleh karena itu kecakapan untuk hidup (lifeskill) dapat didefinisikan

9 Jhon M.Echols dan Hasan Shdaly, Kamus Inggris Indonesia (Jakarta: PT Gramedia Pustaka Utama, 1976), 356.

${ }^{10}$ WJS Poerwodarminto, Kamus Besar Bahasa Indonesia (Jakarta: Balai Pustaka,1987), 179. 
sebagai suatu kepandaian, kemahiran, kesanggupan atau kemampuan yang ada pada diri seseorang untuk menempuh perjalanan hidup atau untuk menjalani kehidupan.

Konsep pendidikan kecakapan hidup adalah bentuk pengembangan kurikulum pendidikan yang menekankan pola kecakapan hidup. Kecakapan hidup adalah sebagai kontinium pengetahuan dan kemampuan yang diperlukan oleh seseorang untuk berfungsi secara independen dalam kehidupan. Esensinya yaitu kemampuan, kesanggupan, dan ketrampilan yang diperlukan oleh seseorang untuk menjalankan kehidupan dengan nikmat dan bahagia.

1. Landasan Pendidikan Kecakapan Hidup

Agama Islam menekankan kepada umatnya untuk hidup yang baik, bahagia dunia dan akhirat. Umat Islam diperintahkan untuk menjaga keseimbangan antara urusan dunia dan urusan akhirat, antara jasmani dan rohani, kebahagian lahir dan batin.

2. Prinsip-Prinsip Pendidikan Kecakapan Hidup

Prinsip-prinsip pendidikan kecakapan hidup (lifeskill) yaitu: ${ }^{11}$ a) Tidak mengubah sistem pendidikan yang telah berlaku, b) Tidak harus mengubah kurikulum, tetapi yang diperlukan adalah penyiasatan kurikulum untuk diorientasikan pada kecakapan hidup, c) Etika socio-religius bangsa sedapat mungkin diintegrasikan dalam proses pendidikan; d) Menggunakan prinsip learning to know (belajar untuk mengetahui sesuatu), learning to do (belajar untuk menjadi dirinya sendiri), dan learning to life together (belajar untuk hidup bersama); e) Paradigma learning for life and school forwork dapat menjadi dasar kegiatan pendidikan, sehingga mempunyai pertautan dengan dunia kerja; f) Penyelenggaraan pendidikan harus mengarahkan peserta didik agar; g) membantu mereka untuk menuju hidup yang sehat dan bahagia; h) mendapatkan pengetahuan dan wawasan yang lebih luas; i) memiliki akses untuk mampu memenuhi standar hidupnya secara layak.

${ }^{11}$ M. Sulthon Masyhud dan Moh. Khusnurdiko, Manajemen Pondok Pesantren (Jakarta: Diva Press, 2004), 163-164. 
3. Pembagian Pendidikan Kecakapan Hidup

Berkenaan dengan pembagian pendidikan jenis kecakapan hidup, terdapat beberapa hal, yaitu ${ }^{12}$ :

a. Kecakapan mengenali diri (selfawarenes); kemampuan personal: kemampuan penghayatan di sebagai makhluk Tuhan, anggota masyarakat dan warga negara yaitu keimanan kepada Tuhan Yang Maha Esa. Manusia sebagai homo divinans (makhluk yang berketuhanan), dengan fitrah manusia untuk beragama.

b. Kecakapan berpikir rasional (thinking skill): kecakapan menggali dan menemukan informasi, mengolah informasi dan mengambil keputusan, memecahkan masalah secara kreatif.

c. Kecakapan sosial atau kecakapan antar personal yaitu meliputi kemampuan komnikasi empati dan kecakapan bekerjasama.

d. Kecakapan akademik. Kecakapan ini merupakan pengembangan dari kecakapan berpikir rasional yang bersifat umum.

e. Kecakapan vokasional yaitu kecakapan yang dikaitkan dengan pekerjaan tertentu yang terdapat di masyarakat.

4. Tujuan Pendidikan Life Skill

Tujuan dari pendidikan Life Skill ialah dimilikinya kemampuan memecahkan masalah secara bertanggung jawab. Untuk mencapai tujuan tersebut, maka harus terlebih dahulu melalui dua tujuan antara lain; mampu mengenali hakikat dirinya, potensi dan bakatbakat terbaiknya serta dapat berusaha sekuat tenaga untuk mengaktualisasikan seluruh potensinya, mengekpresikan dan menyatakan dirinya sepenuhnya dengan cara menjadi dirinya sendiri.

Kedua, pendidikan life skill diluar sekolah (pesantren), pelaksanaan program pembelajaran life skill bertujuan institusional adalah untuk mencetak santri yang mukmin muslim taat menjalankan dan menegakkan syariat Islam, berpengetahuan luas dan berfikir bebas dan mampu mengaplikasikan dalam kehidupan nyata dimasyarakat. Ketiga pembelajaran Life Skill melalui magang, istilah magang diartikan sebagai proses belajar dimana seseorang memperoleh dan menguasai suatu keterampilan

${ }^{12}$ M. Arifin, Ilmu Pendidikan Islam (Jakarta: Bumi Aksara, 1996), 32. 
tanpa dan atau dengan petunjuk orang yang sudah trampil dalam bekerja. Proses belajar terjadi dalam bentuk belajar sambil bekerja.

Kegiatan belajar sambil magang merupakan bagian dari kegiatan belajar umat manusia, yang keberadaanya jauh sebelum pendidikan persekolahan lahir dalam kehidupan manusia. Syarat magang adalah orangnya terampil, ada orang tidak atau kurang terampil belajar sambil bekerja, waktu dan tempat, perjanjian kedua belah pihak. Keempat pembelajaran dalam dimensi kewirausahaan, kewirausahaan dalam lembaga kursus secara garis besar ada dua pola umum penyelengaraan pendidikan pada lembaga kursus yaitu: pola terintegrasi adalah pembejaran pendidikan kewirausahaan yang diprogramkan dan dilakukan secara stimulant dengan pelajaran vokasional. Pola terpisah adalah pembelajaran pendidikan kewirausahaan yang diprogramkan dan dilaksanakan secara tersendiri dalam satu kesatuan program khusus. ${ }^{13}$

Telah disebutkan diatas bahwa Life Skill dapat membantu dalam berbagai kegiatan, baik yang dilakukan disekolah maupun diluar sekolah dan berbagai macam pembelajaran. Sedangakan yang dikaji oleh penulis adalah Aktualisasi Pendidikan Life Skill Untuk Meningkatkan Nilai-Nilai Spiritual Santri di Pondok Pesantren Al-Qodiri Jember. pondok pesantren disini penulis ingin mengetahui bagaimana program dan pencapaian hasil melalui pengembangan LifeSkill yang dilakukan oleh lembaga pendidikan di Pondok Pesantren Al-Qodiri Jember dengan tujuan meningkatkan kemandirian santri.

\section{B. Nilai-Nilai Spriritual}

1. Pengertian Spiritual

Istilah Spiritual penting mengenai "roh". ${ }^{14}$ Kata spiritual ini mengacu kepada kosa kata latin sprit atau spiritus yang berarti nafas/ roh. ${ }^{15}$ Dalam kamus ilmiah spiritual dapat diartikan mencakup nilai-

\footnotetext{
${ }^{13}$ Anwar, Pendidikan Kecakapan Hidup (Bandung: CV. ALFABETA, 2015)

${ }^{14}$ Wowo Sunaryo Kuswana, Biopsikologi, Pembelajaran Prilaku (Bandung: Alfabeta, 2014), 259.

${ }^{15}$ Jalaludin, Psikologi Agama (Jakarta: Rajawali Pers, 2011), 330.
} 
nilai kemanusian yang non material, seperti kebenaran, kebaikan, keindahan, kesucian dan cinta rohani, kejiwaan dan intelektual.

Dalam pengertian yang lebih luas spirit dapat diartikan sebagai: 1) kekuatan kosmis yang memberi kekuatan kepada manusia (yunani kuno); 2) sifat kesadaran, kemauan,dan kepandaian yang ada dalam alam menyeluruh; 4) jiwa luhur dalam alam yang bersifat mengetahui semuanya, mempunyai akhlak tinggi, menguasai keindahan, dan abadi; 5) dan dalam agama spirit mendekati kesadaran ketuhanan. ${ }^{16}$

Spiritualitas dalam Islam merupakan salah satu bagian dari pengalaman keberagamaan umat dengan bertumpu pada Allah SWT. Dalam realitanya, terdapat banyak bentuk spiritualitas yang dipraktekkan yaitu salah satunya seperti diterapkan dalam Dzikir Manaqib Syaikh Abdul Qodir Jailani Pondok Pesantren Al- Qodiri Jember. Spiritualitas adalah Islam itu sendiri, sehingga tentunya indikator dari suatu spiritualitas yang dimiliki manusia dapat diamati dari pengamalan nilai-nilai keislaman yang telah dilakukan. Dalam hal ini, seseorang yang dikatakan memiliki tingkat spiritual yang tinggi, yaitu orang yang senantiasa mengamalkan nilai-nilai ajaran Islam sepenuhnya (holistik). Sebagaimana kita ketahui, hakikat orang yang memiliki spiritualitas yang tinggi yaitu, mereka yang mampu memaknai setiap aktivitas hidup menuju manusia seutuhnya (hanif) dan memiliki pola pemikiran yang hanya bersandar hanya kepada Allah. ${ }^{17}$

Orang yang seperti ini adalah orang yang akan menjalankan hidupnya untuk menjadi rahmat bagi semesta alam sesuai dengan visi diturunkannya Islam, yaitu agama rahmatan lil'alamin. Orang yang tidak bermanfaat bagi umat Islam saja, tetapi juga seluruh umat yang ada didunia. Dalam konteks inklusivitas-multikultural, orang yang memilikis piritualitas tinggi adalah orang yang memiliki sikap keterbukaan suatu penganut agama dalam menerima perbedaan baik dari aspek agama, suku, ras, maupun golongan. Inti dari inklusivitas-

\footnotetext{
${ }^{16} \mathrm{Ibid}$

${ }^{17}$ Muhammad Muhyidin, Kasidah-kasidah Cinta: Novel Spiritual Keajaiban Cinta (Yogyakarta: Diva Prees, 2007), 393.
} 
multikultural adalah pandangan dunia yang pada akhirnya di implementasikan dalam kebijakan tentang kesediaan menerima kelompok lain secara sama, sebagai kesatuan tanpa memperdulikan perbedaan budaya, etnik, gender, bahasa ataupun agama". ${ }^{18}$

Didalam Dzikir Manaqib Syaikh Abdul Qodir Jailani Pondok Pesantren Al-Qodiri sebagai wadah inklusivitas-multikultural, implementasi nilai-nilai spiritualitas juga diterapkan. Konstruksi nilai spiritualitas termanifestasikan dalam kegiatan dzikir manaqib yang mengajak semua elemen masyarakat baik dari berbagai suku, agama, ras, golongan, maupun dari luar negeri.

Dzikir manaqib mengajak jamaah semua yang ada dalam elemen SARA (Suku, Agama, Ras dan Antar Golongan) dan tidak memandang status baik rakyat jelata maupun para pejabat untuk diajak beribadah terutama berdzikir dalam rangka mendekatkan diri pada Allah. Mereka yang mengikuti dzikir manaqib itu akan merasaka nkedamaian hati, termotivasi untuk hidup mandiri. Hidup penuh kedamaian dengan orang lain dan sebagainya. Selain itu, dengan berdzikir pada Allah, meniru akhlak nabi dan akhlak wali Allah terutama Sulthonul Auliya' Syaikh Abdul Qodir Jailani, maka kita akan menjadi manusia yang akan mewujudkan Islam Rahmatan Lil'alamin. Salah satu indikasi muslim yang rahmatanlilalamin adalah berperilaku baik, menjaga toleransi, menjaga ukhuwah/ persaudaran dan tidak melakukan perbuatan yang anti SARA.

Dengan berdzikir dan meniru akhlak, maka otomatis kita melestarikan dan mengembangkan nilai-nilai yang ada dalam dzikir manaqib. Sedangkan di Dzikir Manaqib Syaikh Abdul Qodir Jailani Pondok Pesantren Al- Qodiri sebagai wadah inklusivitas-multikultural terdapat nilai-nilai yang dilaksanakan dan dikembangkan. Salah satu nilai tersebut, yaitu nilai ketuhanan, kemanusiaan, persatuan, ukhuwah/ persaudaraan, kebijaksanaan, keadilan, kesederhanaan, kebebasan, kejujuran, kesalehan, dan kemandirian.

${ }^{18}$ Tim Penelitian dan Pengembangan Agama Jakarta, Pendidikan Agama Islam dalam Persepektif Multikulturalisme (Cet. I; Jakarta: PT. Saadah Cipta Mandiri, 2009$), 7$. 
2. Karakter Spiritual

Secara bahasa, karakter dapat diartikan sebagai sifat-sifat kejiwaan, akhlak atau budi pekerti yang membedakan seseorang dari yang lain. Karakter bisa juga berarti tabiat atau watak. Disamping itu, karakter juga dapat dimaknai sebagai cara berpikir dan berperilaku yang khas tiap individu untuk hidup dan bekerja sama, baik dalam lingkup keluarga, masyarakat, bangsa, dan Negara. ${ }^{19}$

Bahkan karakter dapat juga dimaknai sebagai nilai dasar yang membentuk pribadi seseorang. Karakter seseorang dapat dibetuk baik oleh pengaruh hereditas maupun pengaruh lingkungan yang membedakannya dengan orang lain, serta diwujudkan dalam sikap dan perilakunya dalam kehidupan sehari-hari. Ada pandangan yang menyatakan bahwa karakter merupakan sekumpulan kondisi kejiwaan pada diri manusia yang diperolehnya secara kodrati. Karena itu, kondisi kejiwaan tersebut tidak bisa diubah. Dalam pandangan yang demikian, karakte rmerupakan tabiat seseorang yang bersifat tetap, menjadi ciri khas yang membedakan orang yang satu dengan yang lainnya. Sementara itu, ada juga pandangan yang menyatakan bahwa karakter merupakan tingkat kekuatan atau ketangguhan seseorang dalam mengatasi kondisi kejiwaan yang bersifat kodrati itu. Dalam pengertian ini, karakter merupakan proses yang dikehendaki seseorang untuk menyempurnakan kemanusiaannya.

Dari dua pengertian yang saling bertolak belakang diatas, lahir pemahaman tentang karakter yang lebih realistis dan utuh, yakni karakter sebagai kondisi kejiwaan yang belum selesai. Karakter dalam pengertian ini dipandang merupakan kondisi kejiwaan yang bisa diubah dan disempurnakan. Bahkan karakter bisa pula ditelantarkan sehingga tidak ada pengingkatan mutu atau bahkan terpuruk. ${ }^{20}$

Dari pandangan terakhir diatas, lahir pemahaman bahwa karakter sejatinya dapat diubah dan dikembangkan melalui upaya-upaya

${ }^{19}$ Samani, Muchlas dan Hariyahto, Konsep dan Model Pendidikan Karakter (Bandung: PT Remaja Rosdakarya, 2011), 41.

${ }^{20}$ Saptono, Dimensi-dimensi Pendidikan Karakter: Wawasan, Strategi, dan langkah Praktis (Jakarta: Esensi Divisi Penerbit Erlangga, 2011), 54. 
sistematis yang sengaja dirancang untuk itu. Salah satu upaya sistematis itu adalah pembentukan karakter melalui pendidikan karakter.

Bahwa karakter yang baik adalah upaya yang dilakukan dengan sengaja untuk mengembangkan karakter yang baik (goodcharacter) berlandaskan kebajikan-kebajikan (corevirtues) yang secara objektif baik bagi individu maupun masyarakat. ${ }^{21}$ Maka karakter merupakan penanaman kebiasaan (habit) tentang hal-hal yang baik dalam kehidupan, sehingga seseorang memiliki kesadaran dan pemahaman yang tinggi, serta kepedulian dan komitmen untuk menerapkan kebajikan dalam kehidupan sehari-hari.

\section{Hasil Penelitian}

\section{A. Pendidikan Life Skill di Pondok Pesantren Al-Qodiri Jember}

Pendidikan kecakapan hidup merupakan proses pendidikan yang menyiapkan siswa untuk mampu mengaktualisasikan kemampuan dalam mencapai kompetensi, baik sebagai individu ataupun bagian dari masyarakat sosial, kemampuan intelektual yang tinggi, mampu memecahkan permasalah hidup yang dihadapi, siap menjalani hidup mandiri dan bermartabat, serta proaktif ikut menyelesaikan permasalahan yang ada. $^{22}$

Berdasarkan hasil wawancara dengan salah satu pihak pengurus Pondok Pesantren Al-Qodiri 1 Jember, telah dapat penemuan penelitian bahwa pendidikan Life Skill di Pondok Pesantren Al-Qodiri sesuai dengan pendapat diatas. Pendidikan Life Skill, sangat memberikan dan menghasilkan nilai-nilai positif terhadap pesantren, karna santri mampu mengaktualisasikan kemampuan dalam mencapai kompetensi, baik sebagai individu ataupun bagian dari masyarakat sosial, kemampuan intelektual yang tinggi, mampu memecahkan permasalah hidup yang dihadapi, siap menjalani hidup mandiri dan bermartabat, serta proaktif ikut menyelesaikan permasalahan yang ada.

\footnotetext{
${ }^{21}$ Masnur Muslich, Pendidikan Karakter: Menjawab Tantangan Krisis Multidimensional (Jakarta: Bumi Aksara, 2011), 78.

${ }^{22}$ M. Holil, Pesantren Berbasis Life Skill (Yogyakarta: CV. Pustaka Setia), 235.
} 
Dalam hal ini pengurus di bantu oleh pengurus wilayah yang akan menggali bagaimana santri di wilayah itu bisa berbahasa Arab, baca tulis kitab. Proses kegiatan pengurus wilayah membagi masing-masing kelas sesuai dengan level kelasnya ada kelas 1,2 dan 3. Gurunya pun di sesuaikan dengan mata pelajaran masing-masing kelas itu sendiri. Dalam kegiatan wilayah ini pengurus wilayah cuman mengambil 11/2 jam setelah kegiatan Majelis Ta'lim lain halnya ketika Majelis Ta'lim libur pengurus wilayah juga langsung kegiatan wilayah maksimal 1 jam. Untuk kegiatan yang ada di wilaya khususnya walisongo yang pertama ada kegiatan di masing-masing kelas, ada kegiatan tahlil di malam jumaat dan zikir manaqib di malam minggu, trus ada kegiatan diba'iyah, ada kegiatan pidato ada juga kegiatan debat. Jangka pendek program wilayah yaitu mengontrol bagaimana kemampuan anggota wilayah tersebut dalam ke ilmuan Keagamaan, Ilmu Baca Kitab, Bahasa Arab. Kemudian dalam jangka panjang pengurus wilayah tetap mengevaluasi dalam proses ujian, ujian tulis maupun ujian lisan yang kemudian dinilai, selanjutnya nilai tersebut di jadikan sebagai tolak ukur anggota, apakah anggota layak untuk tetap berada di Wilayah Walisongo atau tidaknya ataupun butuh suatu kajian-kajian ilmu khusus kepada mereka. ${ }^{23}$

Hal ini yang di terapkan oleh pengurus Pondok Pesantren Al-Qodiri 1 Jember mulai dari kegiatan belajar mengajar, sarana dan prasarana, dan kegiatan lain sebagainya yang mendukung kemajuan belajar santri dan untuk meningkatkan perkembangan Pondok Pesantren Al-Qodiri. ${ }^{24}$

Observasi yang telah peneliti lakukan ada beberapa hal yang tidak sesuai dengan apa yang peneliti dapatkan di wawancara kepada ketua pengurus dan ketua pengurus wilayah yang pertama santri kurang minat mengikuti kegiatan wilayah, karna ketika selesai sholat jamaah isya, mereka masih ngobrol di serambi masjid, kedua santri tidak mengikuti semua kegiatan yang ada di wilayahnya, mereka merasa bosan karena kegiatan yang di terapkan di wilayah terlalu banyak, sehingga santri

${ }^{23}$ Observasi, Kegiatan life skill di Pondok Pesantren Al-Qodiri Jember, 12 Januari 2020.

${ }^{24}$ Observasi, Penerapan life skill di Pondok Pesantren Al-Qodiri Jember, 12 Januari 2020 . 
merasa kelelahan untuk mengikuti kegiatan tersebut. Ketiga masih belum bisa meecahkan permasalahan yang ada, karna permasalahan yang saat ini ada di Pondok Pesantren yaitu kemalasan santri ketika sekolah, jamaah, dan kegiatan pesantren lainnya. ${ }^{25}$

Dari sini dapat kita lihat bahwa penanaman pendidikan life skill yang di terapkan Pondok Pesantren Al-Qodiri, walaupun masih banyak yang harus di tingkatkan lagi demi meningkatkan kualitas pendidikan di Pondok Pesantren Al-Qodiri, maka dari itu guru tetap membiasakan santri melaksanakan kegiatan-kegiatan belajar yang sesuai kemampuan santri, supaya santri lebih giat dalam belajarnya dan santri bisa fokus dengan kemamuannya.

Jadi kata kecakapan hidup berarti suatu kepandaian, kemahiran, kesanggupan atau kemampuan yang dimiliki oleh seseorang untuk menyelesaikan sesuatu. Oleh karena itu kecakapan untuk hidup (life skill) dapat didefinisikan sebagai suatu kepandaian, kemahiran, kesanggupan atau kemampuan yang ada pada diri seseorang untuk menempuh perjalanan hidup atau untuk menjalani kehidupan.

\section{B. Nilai-Nilai Spiritual Yang di Tumbuhkan Bagi Santri di Pondok Pesantren Al-Qodiri}

Spiritualitas yang tinggi adalah orang yang memiliki sikap keterbukaan suatu penganut agama dalam menerima perbedaan baik dari aspek agama, suku, ras, maupun golongan. Inti dari inklusivitas-multikultural adalah pandangan dunia yang pada akhirnya diimplementasikan dalam kebijakan tentang kesediaan menerima kelompok lain secara sama, sebagai kesatuan tanpa memperdulikan perbedaan Budaya, Etnik, Gender, Bahasa ataupun Agama. ${ }^{26}$

Dalam penemuan penelitian bahwa penanaman nilai-nilai spiritual yang ada di Pondok Pesantren Al-Qodiri dari hasil wawancara beberapa ketua pengurus dan pengurus lainya bahwa pondok pesantren menanamkan nilai- nilai spiritual sebagai berikut:

\footnotetext{
${ }^{25}$ Observasi, Lapangan, 24 Januari 2020.

${ }^{26}$ Tim Penelitian dan Pengembangan Agama Jakarta, 7.
} 


\section{Nilai Sosial}

Nilai sosial Pondok Pesantren Al-Qodiri yaitu Pondok Pesantren yang dikelilingi dengan rumah masyarakat, disanalah kesempatan seorang santri mempraktekkan apa yang di dapat selama belajar di pondok pesantren, hal kecil yang sering dilakukan santri dengan masyarakat yaitu gotong royong seperti melakukan kegiatan jumaat bersih, dan membantu masyarakat ketika ada perbaikan rumah.

2. Nilai Etika

Akhlak yang di ajarkan santri di Pondok Pesantren Al-Qodiri yaitu bagaimana santri ketika menghadap robnya harus benar-benar rapi tidak berpakaian yang aneh-aneh seperti kemeja yang banyak gambar tengkoraknya, tidak menggunakan kaos ketika sholat berjamaah, dan tidak boleh ngomong ketika sholat. Akhlak santri ketika sesama yaitu bertemu orang tua dan guru cium tangan serta ketika bertemu teman saling bersalaman dan saling mengucap assalamualaikum dan senyum guna untuk mendapat pahala dan memper erat tali persaudaraan.

3. Nilai Moral

Seseorang yang bermukim di pondok pesantren adalah dia yang di anggap santri dan mau belajar ilmu agama, guru yang menjadi panutan bagi santri, guru harus benar-benar mengajarkan nilai etika seperti yang di terapkan di Pondok Pesantren Al-Qodiri di antaranya santri dilarang membuang sampah sembaranagn, santri di larang keluar pondok tanpa kopiah, santri dilarang berbicara kotor dengan teman atau pun dengan yang lainnya.

4. Nilai Kerja Sama Dan Kebersamaan

Nilai kebersamaan dan kerja sama di pondok pesantren itu sudah jadi adat istiadat, yang selalu bekerja sama dan saling tolong menolong, Pondok Pesantren Al-Qodiri Jember, yaitu ketika teman dalam kesusahan di keungannya sebagai teman yang di anggap saudara harus meminjamkan uangnya ke yang membutuhkan, juga apabila ada teman yang kelaparan teman dekatnyalah yang membelikan nasi tersebut, itulah suatu bentuk kebersamaan seperti pepatah santri yaitu sesama saudara saling membatu dalam hal apapun. 
Orang yang menerapkan nilai-nilai diatas adalah Orang yang akan menjalankan hidupnya untuk menjadi rahmat bagi semesta alam sesuai dengan visi diturunkannya Islam, yaitu agama rahmatan lil 'alamin. Orang yang tidak bermanfaat bagi umat Islam saja, tetapi juga seluruh umat yang ada di dunia. ${ }^{27}$

Di dorong dengan motivasi oleh kyai, jadi selain kyai mengajar tafsir al-qur'an kyai juga menganjurkan dan mewajibkan santri-santi untuk menerapkan nilai-nilai keagamaan yang khas di Pondok Pesantren AlQodiri ini yaitu zikir manaqib kemudian ada juga Dzikiran-zikiran khusus setelah sholat yang di baca hanya di Pondok Pesantren Al-Qodiri pondok lain tidak ada, itu termasuk penanaman nilai-nilai spiritual yang kita kembangkan di Pondok Pesantren Al-Qodiri. Ada juga yang melakukan kalau bahasa pondok disini riyadoh, yang dimaksud riyado itu ada santri khusus yang melakukan kegiatan khusus yang dibimbing langsung oleh kyai, biasanya anak-anak santri kalau mau minta bimbingan spiritual khusus itu, mintanya malam minggu kemudian di beritahu atau dikasih arahan, semisal nanti kamu melakukan bacaan yang di beri kyai, dan melakukan puasa beberapa hari, itu merupakan bimbingan spiritual khusus yang dilakukan tidak semua santri. ${ }^{28}$

KH. Achmad Muzakki Syah dawuh kepada santri untuk mengajarkan tentang penerimaan perbedaan terhadap agama lain dan tentang akidah atau keyakinan lewat dzikir manaqib, kyai juga mengingatkan bahwasanya santri harus tetap menanamkan nilai-nilai syariat agama islam tanpa meninggalkan syariat, santri juga melakukan pencerahan, penguatan keyakinan lewat dzikir manaqib, sesuai dengan apa yang menjadi misinya Pondok Pesantren Al-Qodiri yang salah satunya adalah mendidik santri agar memiliki kekokohan akidah. Kedalaman spiritual, keluasan ilmu dan keterampilan serta keluhuran budi pekerti. ${ }^{29}$

Observasi yang peneliti lakukan untuk mencari data yang sesuai dengan pendapat para ahli. Dalam hal ini peneliti melihat sebagian santri yang kurang ikut andil terhadap dzikir manaqib, pertama ketika kiyai

\footnotetext{
${ }^{27}$ Tim Penelitian dan Pengembangan Agama Jakarta, 7.

${ }^{28}$ Observasi, Motivasi K.H Achmad Muzakki Syah, Jember 15 Februari 2020.

${ }^{29}$ Dokumen, K.H Achmad Muzakki Syah kepada Santri, Jember 17 Februari 2020.
} 
mengingatkan santri untuk ikut dzikir manaqib pada malam hari, tapi santri sibuk dengan sendirinya, memilih bercanda bersama temannya, padahal kiyai mengingatkan kalau santri tidak tidur wajib ikut dzikir manaqib malam, bukan hanya dzikir manaqib malam saja bahkan malam jumaat juga hampir sama sebagian yang ikut dzikir manaqib.

Kedua ketika jamaah sebagian santri masih bermalas-malasan ke tempat wudhu padahal sudah di kontrol sama keamanan tapi masih telat jamaah karena masih ada yang tidur di tempat wudhu, ngobrol, bercanda, bercerita, bahkan ada yang ngumpet di dalam kamar mandi dengan alasan sakit perut padahal tidur, itulah kurangnya kesadaran santri terhadap nilai-nilai spiritual di Pondok Pesantren Al-Qodiri Jember. ${ }^{30}$

\section{Penutup}

Berdasarkan hasil penelitian dan kajian teori tentang Aktualisasi Pendidikan Life Skill Untuk Meningkatkan Nilai-Nilai Spiritual Santri di Pondok Pesantren Al-Qodiri 1 Jember tahun 2019/2020, di tarik kesimpulan sebagai berikut :

1. Pendidikan Life Skill sangat memberikan dan menghasilkan nilai-nilai positif terhadap pesantren dikarenakan santri mampu mengaktualisasikan kemampuan dalam mencapai kompetensi baik sebagai individu ataupun bagian dari masyarakat sosial. Kemampuan intelektual yang tinggi mampu memecahkan permasalah hidup yang dihadapi untuk menjalani kehidupan yang mandiri dan bermartabat serta proaktif dalam ikut menyelesaikan permasalahan yang ada. Pengurus Pondok Pesantren Al-Qodiri menempatkan santri di wilayah yang sesuai dengan kemampuan dari masing-masing santri dan di bantu pengurus wilayah untuk terus menggali potensi santri dengan kegiatan wilayahnya. Santri diwilayah ditekankan bisa berbahasa arab dan baca tulis kitab. Selain itu juga aktif mengikuti majelis ta'lim, tahlilan dan dzikir manaqib. Sebagai bahan evaluasinya di laksanakan ujian tulis dan ujian lisan, sebagai tolak ukur kemampuan dan kapasitas santri. Penanaman

\footnotetext{
${ }^{30}$ Observasi, Pondok Pesantren Al-Qodiri Jember, 17 Februari 2020.
} 
pendidikan life skill yang di terapkan Pondok Pesantren Al-Qodiri masih banyak yang harus di tingkatkan lagi demi meningkatkan kualitas pendidikan di Pondok Pesantren Al-Qodiri.

2. Penanaman nilai-nilai spiritual yang ada di Pondok Pesantren AlQodiri di antaranya :
a. Nilai sosial
b. Nilai etika
c. Nilai moral
d. Nilai kerja sama dan kebersamaan

Selain itu juga didorong dengan motivasi dari kyai disaat mengajar tafsir al-qur'an menganjurkan dan mewajibkan santri-santi untuk menerapkan nilai-nilai keagamaan yang khas di Pondok Pesantren Al-Qodiri ini yaitu dzikir manaqib juga ada dzikiran-dzikiran khusus yang di baca setelah sholat di Pondok Pesantren Al-Qodiri hal tersebut termasuk dalam penanaman nilai-nilai spiritual yang dikembangkan di Pondok Pesantren Al-Qodiri.

\section{Daitar Pustaka}

Arifin, M. Ilmu Pendidikan Islam, Jakarta: Bumi Aksara, 1996.

Anwar. Pendidikan Kecakapan Hidup, Bandung: CV. ALFABETA, 2015.

Desmita. Psikologi Perkembangan, Bandung: Rosda Karya, 2007.

HR. Muslim, No. Hadits 2703.

Holil, M. Pesantren Berbasis Life Skill, Yogyakarta: CV. Pustaka Setia, 2015.

Jalaludin. Psikologi Agama, Jakarta: Rajawali Pers, 2011.

Jurnal EMPOWERMENT, Volume 3, Nomer 1 Febuari 2015, ISSN No. 2252-4738.

Kuswana, Wowo Sunaryo. Biopsikologi, Pembelajaran Prilaku Bandung: Alfabeta, 2014. 
Langgung, H. Azas-Azas Pendidikan Islam, Jakarta: Pustaka Al-Husna, 2008.

Masyhud, M. Sulthon dan Moh. Khusnurdiko. Manajemen Pondok Pesantren, Jakarta: Diva Press, 2004.

Muhyidin, Muhammad. Kasidah-kasidah Cinta: Novel Spiritual Keajaiban Cinta. Yogyakarta: Diva Prees, 2007.

Muslich, Masnur. Pendidikan Karakter: Menjawab Tantan gan Krisis Multidimensional. Jakarta: Bumi Aksara, 2011.

M. Echols, Jhon., dan Hasan Shdaly. Kamus Inggris Indonesia, Jakarta: PT Gramedia Pustaka Utama, 1976.

Poerwodarminto, WJS. Kamus Besar Bahasa Indonesia, Jakarta: Balai Pustaka, 1987.

Kemenag RI. Al-Quran dan Terjemahnya, Jakarta Selatan: PT. Hati Emas, 2014.

Samani, Muchlas dan Hariyahto. Konsep dan Model Pendidikan Karakter Bandung: PT Remaja Rosdakarya, 2011.

Saptono. Dimensi-dimensi Pendidikan Karakter: Wawasan, Strategi, dan langkah Praktis. Jakarta: Esensi Divisi Penerbit Erlangga, 2011.

Khasinah, S. Hakikat Manusia Menurut Pandangan Islam dan Barat, Jurnal Ilmiah Didaktika, XIII(2), 2013.

Tim Penelitian dan Pengembangan Agama Jakarta. Pendidikan Agama Islam dalam Persepektif Multikulturalisme, Cet. I; Jakarta: PT.Saadah Cipta Mandiri, 2009. 